\title{
Maatilayrittäjät maatalouskoneiden ja -laitteiden tuotekehityksen tukena
}

\author{
Jenni Koski $^{1)}$, Sanna Kankaanpää ${ }^{2)}$, Janne Aho ${ }^{3)}$, Kari Alasaari ${ }^{4)}$ \\ 1) Frami Oy, Tiedekatu 2, 60320 Seinäjoki, jenni.koski@frami.fi \\ 2) Frami Oy, Tiedekatu 2, 60320 Seinäjoki, sanna.kankaanpaa@frami.fi \\ ${ }^{3)}$ SeAMK, Ilmajoentie 525, 60800 Ilmajoki, janne.aho@seamk.fi \\ ${ }^{4)}$ Helsingin yliopisto, Ruralia-instituutti, Kampusranta 9C, 60320 Seinäjoki, kari.alasaari@helsinki.fi
}

\section{Tiivistelmä}

Agro Living Lab on hanke, jossa maa- ja metsätalouden koneiden, laitteiden ja palveluiden tuottajat sekä loppukäyttäjät - maanviljelijät ja koneurakoitsijat - kohtaavat. Hankkeessa on kehitetty menetelmiä ja toimintatapoja, joilla käyttäjän näkemys, kokemus ja mielipiteet saadaan mukaan valmistajien tuotekehitysprosessiin. Näin huomioimalla käyttäjän tarpeet valmistajat saavat ajantasaista ja maanläheistä tietoa oman tuotekehityksensä lähdeaineistoksi. Maatilayrittäjille hyödyt tulevat konkreettisiksi helppokäyttöisempinä ja turvallisempina koneina ja laitteina, helpommin omaksuttavina palveluina, sekä sitä myöten säästettynä työaikana.

Hankkeessa on kerätty käyttäjäverkosto, johon kuuluu n. 200 maatilayrittäjää Etelä-Pohjanmaan alueelta. Verkostossa on edustettuna kaikki maatilatalouden tuotantosuunnat. Verkoston avulla on tehty lukuisia menetelmäpilotointeja, joihin jäseniä on kutsuttu testaajiksi, ideoijiksi sekä arvioijiksi. Lisäksi jäsenistölle on järjestetty erilaisia kokoontumisia ja opintomatkoja, joissa on ollut mahdollisuus saada ajantasaista tietoa alan kehityksestä ja verkostoitua muiden jäsenien kesken.

Keskeistä toimintaa hankkeessa ovat olleet erilaiset menetelmäpilotoinnit. Nämä voidaan jakaa kolmeen ryhmään: Käyttäjä- ja käyttöympäristötutkimukset, käytettävyystestaukset sekä käyttäjälähtöiset innovaatiomenetelmät. Pilotoinnit on tehty tiiviissä yhteistyössä maatilayrittäjien sekä hankkeen yhteistyöyrityksien kanssa. Agro Living Lab:n osaamista on ollut kehittää ja tuoda tilaisuuksiin menetelmät ja toimintatavat, joilla kukin tilaisuus on toteutettu.

Käyttäjä- ja käyttöympäristötutkimuksissa käytetään yleisimmin erilaisia haastattelu- ja kyselytekniikoita. Hankkeessa on tutkittu ja kehitetty $\mathrm{mm}$. ryhmähaastattelua, teemahaastattelua sekä tilalla tapahtuvaa haastattelua. Kyselytutkimuksia on tehty niin kohdennetusti tietyn profiilin omaaville käyttäjille kuin yleisesti käyttäjäverkoston jäsenille.

Käytettävyystestauksissa on testattu niin pieniä kuin suuriakin koneita ja laitteita. Testauksia on tehty keskitetysti opetustilalla tai käyttäjäverkoston jäsenien omilla tiloilla, jonne testattavat laitteet on viety. Tunnetut testimenetelmät on räätälöity kuhunkin tapaukseen paremmin sopivaksi.

Käyttäjälähtöisiksi innovaatiomenetelmiksi on kehitetty erilaisia ideointi- ja arviointityöpajoja, joissa käyttäjäverkoston jäsenillä on ollut mahdollisuus arvioida olemassa olevia ideoita ja tuotteita tai kehitellä ja ideoida täysin uusia ratkaisuja tiettyyn kysymysasetteluun. Aiheet ovat voineet olla teknisiä tai palvelullisia haasteita, joihin on toivottu suoraa palautetta maatilayrittäjiltä.

Agro Living Lab -hankkeen toteuttaa Frami Oy, Seinäjoen ammattikorkeakoulun maa- ja metsätalouden yksikkö sekä Helsingin yliopiston Ruralia-instituutti. Rahoittajina ovat Etelä-Pohjanmaan ELY-keskus, Seinäjoen seutu, Kauhavan kaupunki sekä viisi yhteistyöyritystä.

Asiasanat: käytettävyys, käyttäjä, käyttäjäverkosto, Agro Living Lab, maatalouskone 


\section{Johdanto}

Käytettävyys on tuotteen ominaisuus, joka määrittelee, kuinka hyvin käyttäjä pystyy hyödyntämään tuotteen toimintoja tehtävissään ja kuinka helppoa on toimintojen käytön oppiminen. Hyvä käytettävyys havaitaan tuotteen käytön helppoutena, nopeutena ja miellyttävyytenä; valmistajan kannalta se on helppo myydä ja vaatii vähemmän käyttökoulutusta sekä ylläpitotukea.

Tuotteen hyödyllisyys ja käytettävyys voidaan vielä eritellä toisistaan (kuvio 1.). Hyödyllisyydessä (utility) on kyse järjestelmän toiminnallisuuden soveltuvuudesta tehtäväänsä. Käytettävyys (usability) on sitä, kuinka hyvin käyttäjät voivat käyttää tätä toiminnallisuutta. Hyödyllisyys ja käytettävyys ovat yhdessä osa järjestelmän käyttökelpoisuutta (usefulness), joka edelleen on osa järjestelmän hyväksyttävyyttä (acceptability). Käytännön hyväksyttävyys koostuu kustannuksista, yhteensopivuudesta ja hyödyllisyydestä, joista viimeiseen käytettävyys sisältyy. Järjestelmän hyväksyttävyyteen puolestaan kuuluu sosiaalinen ja käytännöllinen hyväksyttävyys. (Nielsen 1993, 24-26.)

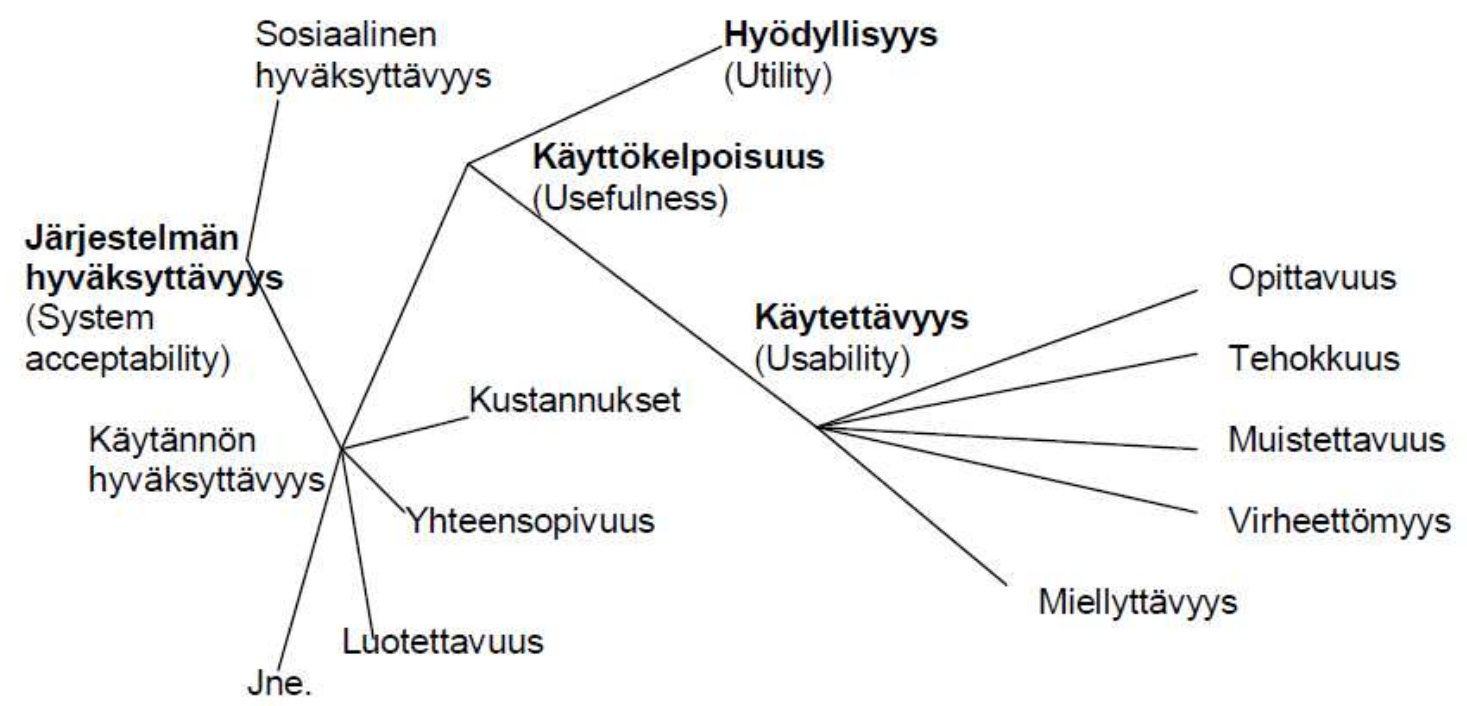

Kuvio 1. Käytettävyys osana järjestelmän hyväksyttävyyttä. Nielsenin (1993) malli käytettävyyden osatekijöistä.

Käytettävyyttä ja käyttäjälähtöisyyttä pyritään selvittämään livin lab -toiminnan avulla. Living lab:n määritelmiä on lukuisia, eikä sille ole olemassa vielä yhtenäistä ja virallista määritelmää. Living lab Oravan (2009) mukaan sisältää neljä ydinelementtiä, joiden avulla living lab -toimijat voivat luoda oman käytännön toimintamallinsa. Neljä peruselementtiä on:

- Käyttäjälähtöisyys, käyttäjä on aktiivinen ja tasa-arvoinen toimija.

- Ekosysteemi koostuu kaikista living lab:ssa mukana olevista toimijoista.

- Avoimet innovaatiot ovat kaikille ekosysteemin toimijoille avoimia ja käytettävissä.

- Tosielämän ympäristö. jossa käyttäjä käyttää tuotetta ja jossa living lab toteutetaan.

Living lab -konsepti on laaja-alaiseksi levinnyt toimintamalli, jossa jokaiselle yhteiskunnan jäsenelle tarjotaan mahdollisuus osallistua oman elinympäristönsä kehittämiseen. Toiminnan keskeisenä osana on käyttäjän havainnoiminen hänen omassa elinympäristössään tai sitä imitoivissa olosuhteissa. Tavoitteena on löytää sellaisia tarpeita ja toiveita, joiden täyttämiseksi voidaan kehittää ratkaisuja esimerkiksi uusien tuotteiden ja palveluiden avulla. Living lab -konsepti koostuu neljän toimijajoukon yhteistyön tuloksena. Nämä ovat kehittäjät, hyödyntäjät, mahdollistajat ja käyttäjät. Kehittäjät tarjoavat living lab:lle työkaluja ja menetelmiä, hyödyntäjät saavat hyödyllistä tietoa omaan tuotekehitykseensä living lab:Itä, mahdollistajat luovat yleiset puitteet living lab:n toiminnalle ja käyttäjät jakavat henkilökohtaista osaamistaan living lab:n toiminnassa. Agro Living Lab:ssa kehittäjinä toimivat projektihenkilöstö, hyödyntäjinä yhteistyöyritykset, mahdollistajina kolme toteuttajakumppania, Frami Oy, Seinäjoen ammattikorkeakoulu sekä Helsingin yliopiston Ruralia -instituutti sekä käyttäjinä maatilayrittäjät.

Agro Living Lab on maa- ja metsätalouskoneiden käytettävyyteen ja käyttäjälähtöisen suunnittelun lisäämiseen keskittynyt living lab, joka toimii Etelä-Pohjanmaan alueella. Agro Living Lab on kolmen organisaation yhteishanke, jossa kehitetään käyttökelpoisia menetelmiä ja toimintatapoja toi- 
mialan koneiden, laitteiden ja palveluiden käyttäjäkeskeiseen suunnitteluun. Hanke on syystäkin syntynyt juuri Etelä-Pohjanmaan alueelle: maakunta on vahvaa maatalousaluetta ja alueella sijaitsee paljon maatalouskoneisiin erikoistunutta teollisuutta. Näin ollen puitteet Agro Living Lab:n kaltaiselle toiminnalle olivat jo luonnostaan olemassa.

\section{Aineisto ja menetelmät}

Agro Living Lab -hankkeen tavoitteina on (Esala, Kankaanpää, 2010):

1. Lisätä maa- ja metsätalouden teknologian loppukäyttäjille kehitettävien koneiden ja laitteiden käytettävyyttä sekä niiden tuottamaa lisäarvoa.

2. Edistää maa- ja metsätalouden teknologian kansainvälisen tason living lab - toimintaa, joka yhdistää käyttäjäkeskeisen suunnittelun, käytettävyyden ja käyttöturvallisuuden tutkimuksen, kehittämisen ja testauksen maa- ja metsätalouden koneisiin ja laitteisiin.

3. Aktivoida maa- ja metsätalouden kone- ja laitevalmistajia yhteistyöhön käyttäjien kanssa sekä varmistaa käyttäjätarpeiden huomioiminen oikea-aikaisesti yrityksen tuotekehitysprosessissa.

Agro Living Lab -hankkeen tavoitteita on toteutettu kahden aineistolajin yhteistyöllä. Näitä ovat käyttäjäverkostossa olevan tiedon ja taidon tuoma vahva näkemys koneiden ja laitteiden ominaisuuksista ja käytöstä sekä yhteistyöyrityksien tuotekehityksestä tuleva nykyaikainen tekninen tieto samoista koneista ja laitteista. Agro Living Lab:n rooli on ollut olla eräänlainen kehitysalusta, jonka välityksellä nämä kaksi tietopohjaa on saatettu yhteen.

Hankkeen tärkein ja käytetyin tiedonlähde on koottu käyttäjäverkosto, johon kuuluu noin 200 eteläpohjalaista maatilayrittäjää. Käyttäjäverkostoa on kasvatettu monilla eri menetelmillä koko hankkeen ajan. Näitä ovat erilaiset viestintäkampanjat, messuilla esillä oleminen, lehtiartikkelit sekä henkilökohtaiset kontaktit. Käyttäjäverkoston asiantuntemus on otettu huomioon kaikissa tutkimusongelmien määrittelyissä sekä menetelmäpilotointien suunnittelussa ja toteutuksessa. Käyttäjäverkoston jäsenistöä on käytetty myös apuna hankkeen toiminnan ja uusien toimenpiteiden suunnittelussa.

Käyttäjäverkoston ikähaarukka on 18-65 vuotta. Suurimmaksi osaksi jäsenet ovat 35-50 vuotiaita miehiä. Enemmistö käyttäjistä harjoittaa maatilallaan kasvinviljelyä sekä jonkinasteista urakointitoimintaa. Toiseksi suurin ryhmittymä ovat maidontuottajat. Naisia verkostossa on varsinaisina jäseninä muutamia, mutta useampia maatilojen emäntiä on pyritty kontaktoimaan hankkeen aikana maatilojen isäntien välityksellä. Yhteistä kaikille verkoston jäsenille on vapaaehtoisuus ja innokkuus hankkeen toimintaa kohtaan. On ollut selvästi havaittavissa, että maatilayrittäjiltä on puuttunut selkeä kanava esittää toiveitansa ja kehitysehdotuksiansa maatalouden koneisiin ja laitteisiin. Tähän tarpeeseen on Agro Living Lab -hanke vastannut tarjoamalla suoria vaikutusmahdollisuuksia menetelmäpilotointien kautta käyttäjille.

Hankkeessa on ollut mukana viisi yhteistyöyritystä. Yrityksien panos hankkeessa on ollut tarjota sopivia ja aitoja tutkimusongelmia hyödynnettäväksi menetelmäkehityksessä. Aiheet ovat vaihdelleet koneiden ja laitteiden käytettävyyden arvioinneista palvelutuotteiden muotoiluun sekä tiettyjen aihekokonaisuuksien ideointiin. Tämä osaltaan on auttanut motivoimaan tutkimuksiin osallistuneita käyttäjiä. Aidon tutkimusongelman käsittely on tullut lähelle todellisuutta, jolloin käyttäjillä on syntynyt positiivinen tunne heidän mahdollisuuksistaan vaikuttaa kyseessä olevan koneen, laitteen tai palvelun käytettävyyteen ja tuotekehitykseen. Yritykset tuotteineen on valittu edustamaan laajasti viljelykierrossa ja maatilojen tuotantoprosesseissa käytettyjä koneita, laitteita ja palveluita.

Agro Living Lab on kuulunut perustamisestaan lähtien erilaisiin kotimaisiin ja kansainvälisiin living lab -verkostoihin, muun muassa euroopanlaajuiseen ENoLL:in (Europian Network of Living Labs). Verkostojen antama hyöty Agro Living Lab:lle tulee erilaisien yhteistyökontaktien ja verkostojen lisääntymisenä sekä living labien sisällä käytettyjen menetelmien kokemusvaihtona. Hankkeen edetessä living lab -toimintamalli on levinnyt huomattavasti yhä uusille toimialoille. Tästä huolimatta Agro Living Lab on poikkeava muista, koska yksikään muu eurooppalainen living lab ei ole erikoistunut maa- ja metsätalouskoneisiin ja niiden käytettävyyden parantamiseen. 


\section{Tulokset ja tulosten tarkastelu}

Hankkeen tuloksina voidaan esittää koottu käyttäjäverkosto (1) sekä useista erilaisista menetelmistä koostuva menetelmäpankki (2). Lisäksi hankkeessa on määritelty käyttäjälähtöinen tuotekehitysprosessi agroteknologiateollisuuden alalle (3). Menetelmäpankki ja käyttäjälähtöinen tuotekehitysprosessi muodostavat toisiaan tukevan kokonaisuuden, joka palvelee maa- ja metsätalouskonevalmistajia kattavasti tuotteen ideoinnista markkinoille viemiseen saakka.

(1) Hankkeessa koottu käyttäjäverkosto koostuu n. 200 maatilayrittäjästä, jotka edustavat kaikkia maatilatalouden tuotantosuuntia. Käyttäjäverkosto on koottu vapaaehtoisista eteläpohjalaisista maatilayrittäjistä, joilla on ollut mielenkiintoa ja halua osallistua maa- ja metsätalouskoneiden kehitykseen Agro Living Lab -hankkeen kautta. Verkostoa on kerätty aktiivisesti muun muassa viestintäkampanjoilla, alan messuilla esillä olemalla, lehtiartikkeleilla ja mielenkiintoisella toiminnalla. Verkoston ylläpitämiseen ja motivoimiseen on käytetty hankkeen puitteissa toteutettuja opintomatkoja, seminaareja sekä teemallisia keskusteluiltoja. On ollut tärkeää, että käyttäjäverkostolla on ollut monipuolista tekemistä ja kokemista, jotta mielenkiinto hankkeen päätoimintaa, eli käytettävyyden ja käyttäjälähtöisen suunnittelun edistämistä, kohtaan on säilynyt. Verkoston jäseniltä on kysytty ilmoittautumisen yhteydessä tärkeitä profiloivia taustatietoja, jolloin testauksiin ja tutkimuksiin on voitu etsiä juuri tietyn profiilin omaavia käyttäjiä.

(2) Hankkeessa on koottu menetelmäpankkia, joka voidaan jakaa karkeasti kolmeen eri kategoriaan: (a) käyttäjä- ja käyttöympäristötutkimuksen menetelmiin, (b) käytettävyystestauksen menetelmiin sekä (c) käyttäjälähtöisiin innovaatiomenetelmiin. Kunkin kategorian menetelmiä on kehitetty, testattu ja pilotoitu yhdessä niin Seinäjoen ammattikorkeakoulun opiskelijoiden kuin käyttäjäverkoston käyttäjien kanssa.

(2a) Käyttäjä- ja käyttäjätarvetutkimuksessa on kehitetty erilaisia havainnointi-, haastattelu- ja kyselymenetelmiä, jotka erityisen hyvin soveltuvat maatilaympäristöihin ja maatilayrittäjien havainnoimiseen. Haastattelutilanteisiin on löydetty sellaisia toimintatapoja, joiden avulla haastattelutilanteet on saatu luonteviksi ja haastateltava on kokenut olonsa rennoksi. Tällaisia toimintatapoja ovat olleet muun muassa erilaisten virikekuvien käyttö sekä ryhmähaastattelutilanteet. Molemmissa tapauksissa haastattelun kohde on saanut uudenlaisia ajatuksia ja näkökulmia oman ajattelunsa tueksi, joka puolestaan on parantanut haastattelun ilmapiiriä ja luonut parempia edellytyksiä monipuolisiin ja kattaviin tuloksiin.

(2b) Erilaisien maatalouskoneiden käytettävyyden arvioimiseen on hankkeessa kehitetty useita erilaisia testausmenetelmiä. Menetelmät on kehitetty ja sovellettu aina kulloinkin käsillä olevaan tutkimusongelmaan sopivaksi, jolloin niin menetelmästä kuin testituloksista on saatu paras mahdollinen hyöty esille. Yleisesti ottaen testauksen aikana on käytetty paljon ääneen ajattelua, jälkikäteen haastattelua sekä kirjallista palautteen antoa. Lisäksi testitilanteita on kuvattu videolle, joita analysoimalla on löytynyt hyvin paljon sellaisia ongelmia käytettävyydessä, joita testikäyttäjä ei ole pystynyt sanallisesti kuvaamaan testauksen aikana. Hankkeen aikana on tehty ja raportoitu yhteensä kuusi erityyppistä käytettävyystestausta. Näistä esimerkkinä on muun muassa koneiden vertailutestaus, käyttöohjetestaus sekä tehokäyttäjälle suunnattu testaus.

(2c) Innovaatiomenetelmät on tarkoitettu hyvin monenlaisiin käyttötilanteisiin. Tyypillisin menetelmän pilotointi on kohdistunut tuotekehitysprosessin alun ideointivaiheeseen. Tällöin tavoitteena on ollut etsiä käyttäjien avulla uusia ajatuksia ja ideoita jonkin asian ratkaisemiseksi tai löytää sellaisia tarpeita, joita tuotekehittäjät eivät ole aiemmin huomioineet omissa prosesseissaan. Innovaatiomenetelmien avulla on myös arvioitu tuotteiden markkinoinnillisia asioita, palvelujen toimivuutta ja yleistä markkinamielipidettä. Innovaatiomenetelmiä on kehitetty kaksi kappaletta. Yhteistä näille on laaja soveltuvuus monenlaisiin tutkimusongelmiin sekä muokattavuus. Molemmissa menetelmissä käytetään käyttäjäryhmää.

(3) Menetelmäpankin menetelmät pystytään jaottelemaan hankkeessa kehitetyn käyttäjälähtöisen tuotekehitysprosessimallin eri osioihin. Prosessimalli jakautuu neljään vaiheeseen: 1) Alkukehitykseen, jossa tehdään taustatutkimusta ja ideointia, 2) Tuotteen kehitykseen, jossa suunnitellaan tuote, valmistetaan siitä prototyyppejä ja tehdään validoivaa testausta, 3) Tuotantoon vientiin, jossa tuote on valmis markkinoille lanseerattavaksi sekä 4) Ylläpitovaiheeseen, jossa tuote on markkinoilla ja sille voidaan kehittää mahdollisia uusia variaatioita. Käyttäjälähtöinen tuotekehitysprosessimalli ei noudata yrityksissä käytettävää yleistä tuotekehityksen prosessimallia, vaan lähtökohdaksi on otettu, missä eri tuotekehityksen vaiheissa loppukäyttäjiä voidaan hyödyntää tuotekehitysprosessin aikana. 
Jokaiseen menetelmäpilotointiin on käytetty aitoa tutkimusongelmaa, joka on saatu joltakin hankkeen yhteistyöyrityksistä. Tämä on osaltaan vaikuttanut käyttäjien motivaatioon osallistua toimintaan ja testauksiin. Käyttäjillä on halu osoittaa ja jakaa omaa asiantuntemustansa, joka kanavoituu helpolla tavalla tämän tyyppisen toiminnan kautta. Lisäksi käyttäjät ovat kokeneet olevansa vahvasti vaikuttamassa tulevaisuuden tuotekehitykseen, mikä on osaltaan innostanut heitä pysymään aktiivisena.

Käyttäjien rooli eri menetelmissä vaihtelee. Perinteisissä haastattelu- ja kyselytutkimuksissa käyttäjä on pelkästään tiedon antajan roolissa. Lisäksi hän voi halutessaan antaa joitain rajattuja kehitysehdotuksia. Käytettävyysarvioinneissa käyttäjät antavat ja tuottavat tietoa niin sanallisesti kuin sanattomasti. Lisäksi heillä on laajemmat mahdollisuudet antaa parannusehdotuksia, koska ovat kiinteästi kontaktissa tutkimusongelman, eli koneen tai laitteen, kanssa. Innovaatiomenetelmissä käyttäjien rooli on yhdistelmä olemassa olevan tiedon ja käyttökokemuksen kertomista sekä uuden tiedon luomista ja toiveiden ja tarpeiden pukemista sanoiksi ja kehitysideoiksi.

Hankkeen suurimpana haasteena on ollut käyttäjäverkoston ylläpito ja aktivointi. Mittavan verkoston erilaisiin tarpeisiin ja odotuksiin on pyritty vastaamaan monenlaisella toiminnalla niin menetelmäpilotointien kuin muidenkin tapahtumien kautta. Hankkeessa on kehitetty myös avoimia testitilaisuuksia, joihin on kaikilla käyttäjäverkoston jäsenillä ollut mahdollisuus tulla ja osallistua. Tällä on pidetty aktiivisena niitä verkoston jäseniä, jotka eivät ole muuten päässeet mukaan testaajaksi osallistujamäärältään rajattuihin tilaisuuksiin.

Toteutettu menetelmäpankki on hyvin laajapohjainen, käyttäjäverkostoa hyödyntävä ja tutkimusongelmien omistajia hyödyttävä kokonaisuus. Menetelmäpankkia on rakennettu pitäen mielessä sen muokattavuus ja sovellettavuus tapauskohtaisesti, koska tutkimusongelmat ja toimeksiantajien toiveet eivät aina sulaudu sellaisenaan kuvattuihin menetelmiin. Menetelmäkehitystä on tehty kahdella periaatteella: Menetelmä edellä sekä tutkimusongelma edellä. Ensin mainitussa on ensin valittu käytettävä menetelmä, jota pilotoimaan on kehitetty tutkimusongelma. Toisena mainitussa on ensin ollut tutkimusongelma, jonka ympärille on valittu tai kehitetty sopiva tutkimusmenetelmä.

Menetelmien pilotoinneissa on havaittu tärkeäksi ohjata käyttäjiä oikeanlaiseen toimimiseen. Käytettävyysarvioinneissa tämä on tarkoittanut muun muassa rohkaisua ääneen ajatteluun sekä parannusehdotuksien antamiseen. Haastattelututkimuksissa on haastattelutilanne pyritty luomaan luonteltaan rennoksi ja vapautuneeksi. Haastatteluja on tehty mahdollisuuksien mukaan haastateltavien omalla tilalla, jolloin haastateltava on tuntenut olonsa helpommin luontevaksi. Innovaatiomenetelmien osalta ohjaus painottuu keskustelun hengen luontiin, eli annettaisiin kaikille vapaus ryhmässä ideoida vapaasti ilman tyrmäystä. Pilotointitilanteet ovat usein jännittäviä kokemuksia osallistujilleen, jolloin pieni ohjaaminen menetelmien suhteen on tarpeen ja suotavaa. Tuloksien ohjausta ja niihin vaikuttamista on vältetty.

\section{Johtopäätökset}

Agro Living Lab -hankkeessa on pyritty edistämään maa- ja metsätalouskonevalmistajien sekä heidän tuotteiden loppukäyttäjien, eli maanviljelijöiden ja koneurakoitsijoiden, välistä yhteistyötä. Yhteistyö on synnytetty hankkeessa kehitettyjen menetelmien avulla. Menetelmien kehittäminen maa- ja metsätaloudelle tyypillisten laitteiden ja sovellusten vaatimuksia vastaaviksi on ollut haastavaa. Aidot käyttöympäristöt ja työtilanteet luovat omat haasteensa kehitystyölle. Menetelmiä kehitettäessä on pidetty keskeisenä päämääränä luoda ennen kaikkea käyttäjälle turvallinen, mielekäs ja aidontuntuinen tilanne käyttäjäkokemuksen jakamiseen.

Hankkeessa on todettu, että tämän kaltaiselle toiminnalle on kysyntää niin maakunnassa kuin muuallakin Suomessa. Toiminnan avulla on saatu aikaan aitoa yhteistyötä, jonka tuloksia voidaan nähdä tulevaisuudessa tuotettavissa maatalouden koneissa ja laitteissa. Lisäksi toiminnan pohjaksi kehitettyjä toimivia menetelmiä voidaan soveltaa hyvin monenlaisiin käyttötarkoituksiin, joka puolestaan lisää entisestään yhteistyömahdollisuuksien tarjontaa.

Toimenpiteiden oikea-aikaisuus, kaikkien osapuolien avoimuus sekä keskinäinen luottamus toimivat perustana yhteistyön toimivuuden maksimaalisen hyödyn saavuttamiselle. Agro Living Lab on luonut pohjan uudentyyppiselle innovatiiviselle toiminnalle maa- ja metsätalouskonealalla, jonka tuloksia voidaan parhaiten arvioida tulevaisuudessa. Havaittavissa kuitenkin on jo eräänlaista asenne- 
muutosta koneenrakentajien tuotekehitystoiminnassa, sillä yhä enenevässä määrin kuluttajien ja loppukäyttäjien mielipiteet otetaan huomioon uusia tuotteita suunnitellessa. Loppukäyttäjät nähdään yhtenä tuotekehityksen resurssina ja sellaisen tiedon tuottajana, joka ei välttämättä tule esille tavanomaisessa yrityksen sisäisessä tuotekehitystoiminnassa.

\section{Kirjallisuus}

Esala, J \& Kankaanpää,S. 2010. Agro Living Lab. Julkaisussa: Anneli Hopponen (toim.) Maataloustieteen Päivät 12.-13.1.2010 [verkkojulkaisu]. Suomen maataloustieteellisen seuran tiedote no. 26

Nielsen, J. 1993. Usability Engineering. Academic Press Inc., San Diego.

Orava, J. 2009. Living Lab -toiminta Suomessa. Innovaatio ja osaaminen -verkosto / Seinäjoen Teknologiakeskus Oy. Aluekeskusohjelman verkostojulkaisu 3/2009. 